
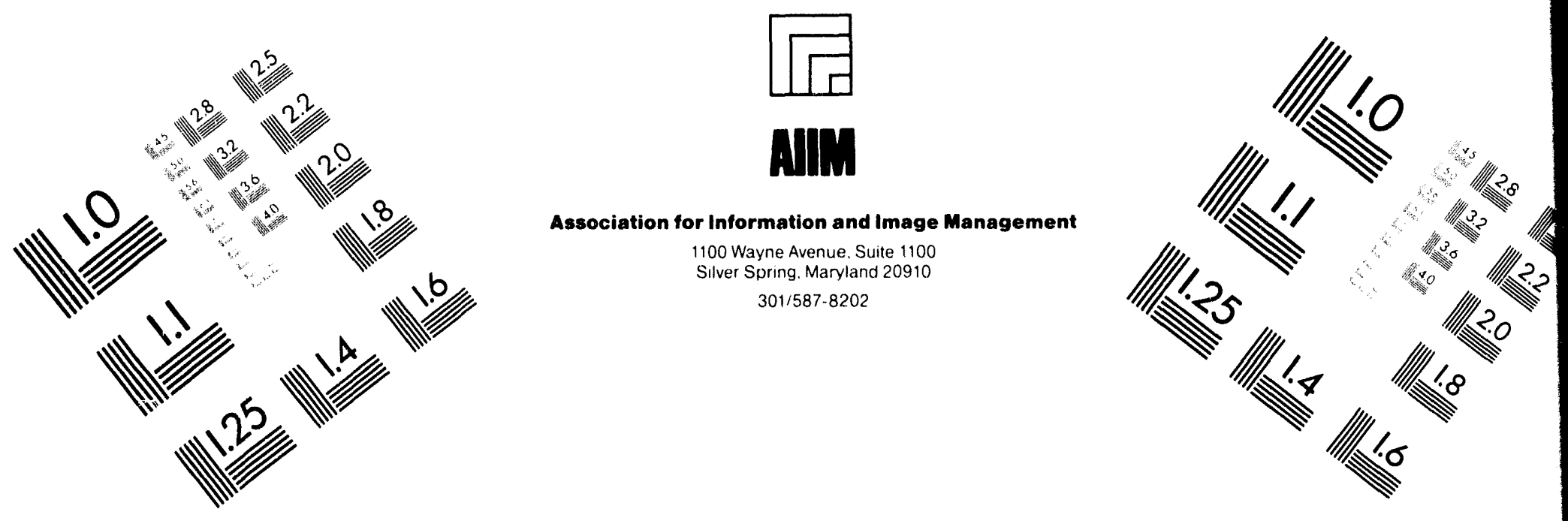

\title{
Centimeter
}

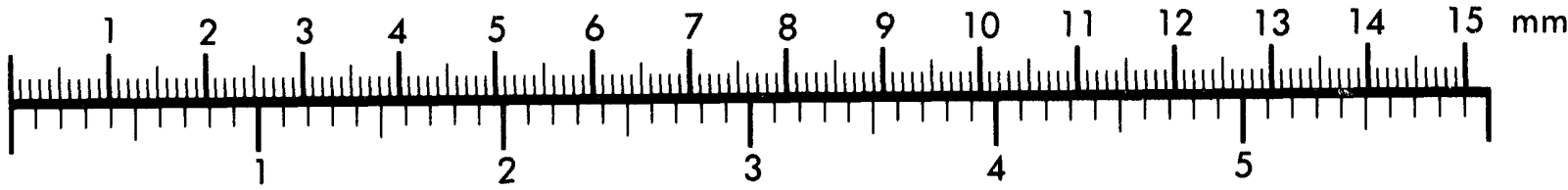

Inches
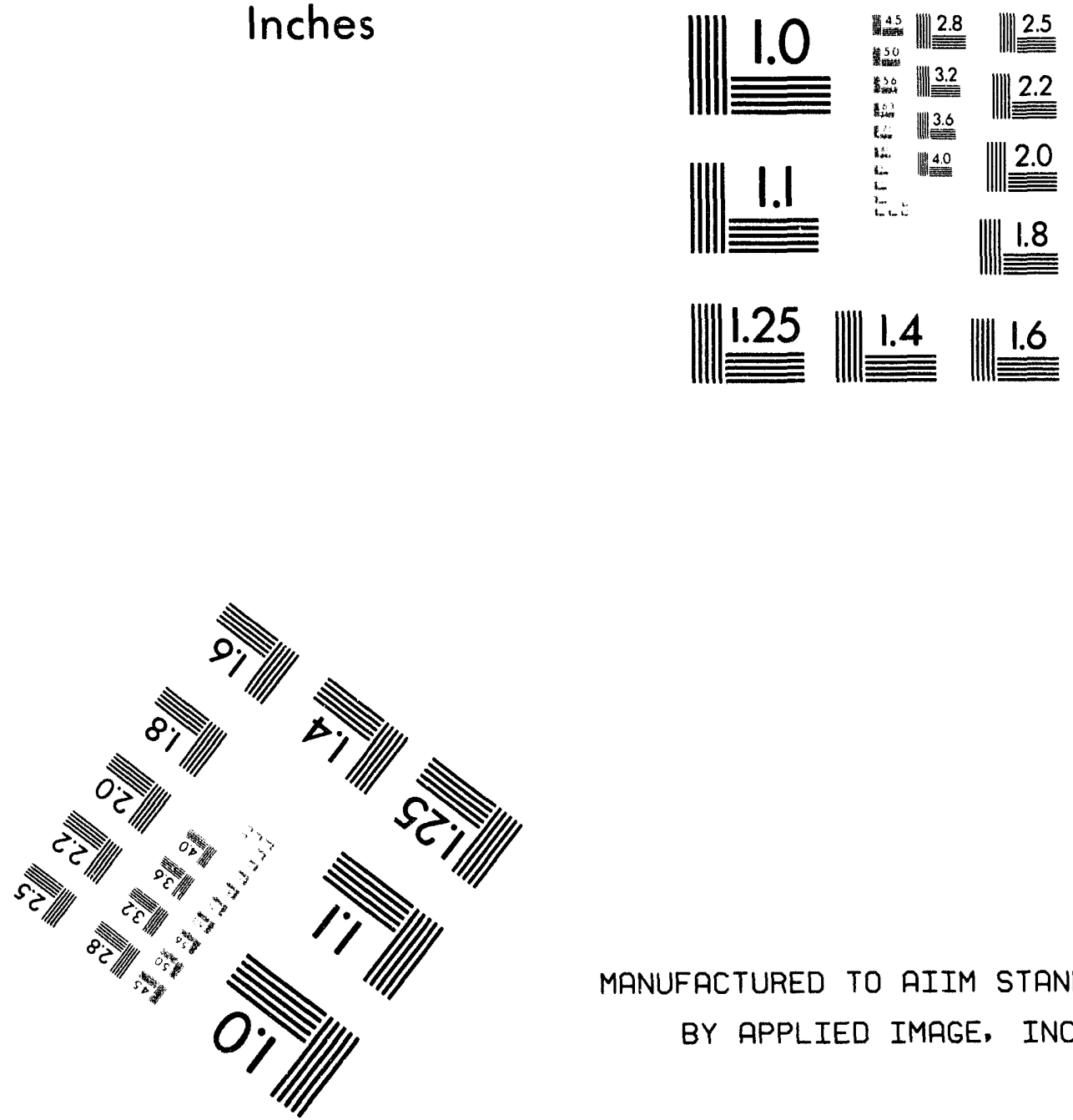

MANUFACTURED TO AIIM STANDARDS

BY APPLIED IMAGE, INC.

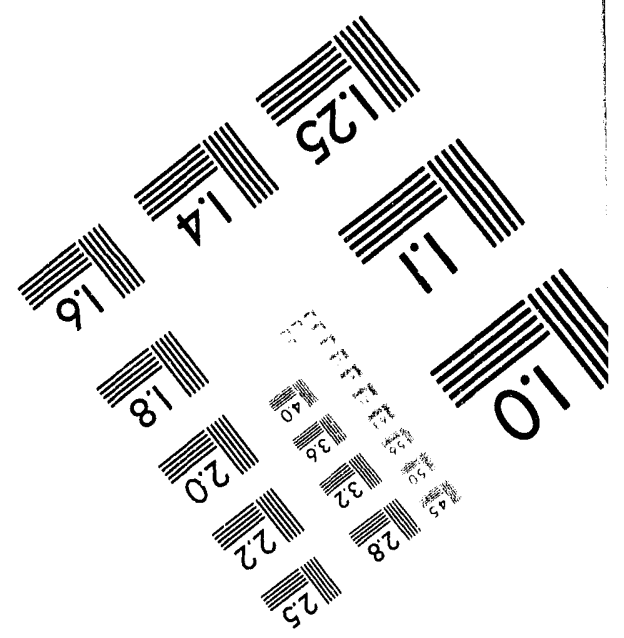



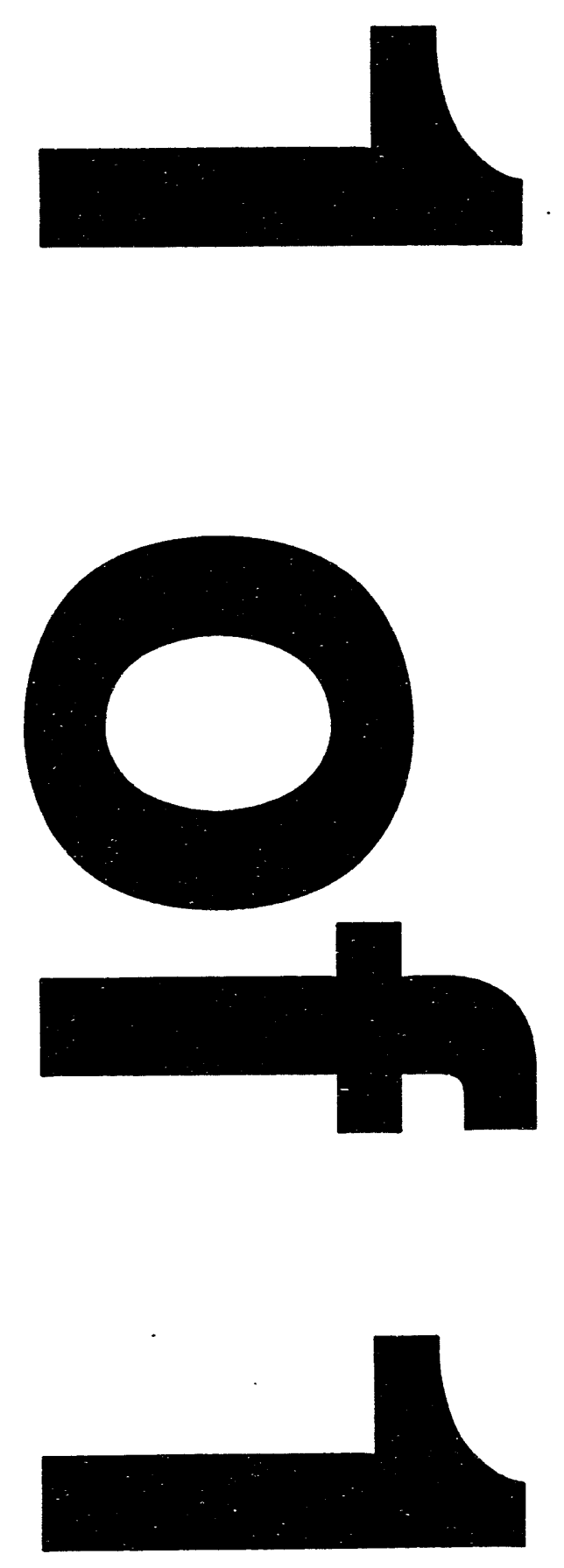


\section{NUCLEAR CRITICALITY SAFETY EVALUATION DWPF MELTER - BATCH 1 (U)}

by

T. G. Williamson

Westinghouse Savannah River Company

Savannah River Site

Aiken, South Carolina 29808

This paper was prepared in connection with work done under the above contract number with the U.S.

Department of Energy. By acceptance of this paper, the publisher and/or recipient acknowledges the U. S. Government's right to retain a nonexclusive, royalty-free license in and to any copyright covering this paper, along with the right to reproduce and to authorize others to reproduce all or part of the copyrighted paper.

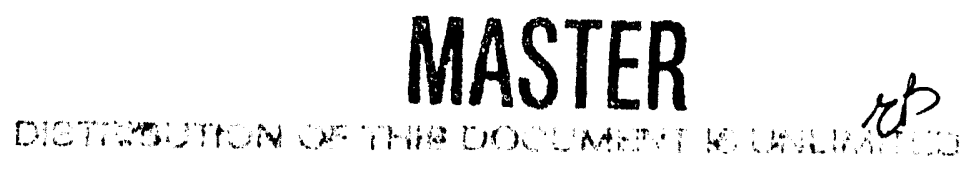




\section{DISCLAIMER}

This report wals prepared as an account of work sponsored by an agency of the United States Government. Neither the United States Government nor any agency thereof, nor any of their employees, makes any warranty, express or implied, or assumes any legal liability or responsibility for the accuracy, completeness, or usefulness of any information, apparatus, product, or process disclosed, or represents that its use would not infringe privately owned rights. Reference herein to any specific commercial product, process, or service by trade name, trademark, manufacturer, or otherwise does not necessarily constitute or imply its endorsement, recommendation, or favoring by the United States Government or any agency thereof. The views and opinions of authors expressed herein do not necessarily state or reflect those of the United States Government or any agency thereof.

This report has been reproduced directly from the best available copy.

Available to DOE and DOE contractors from the Office of Scientific and Technical Information, P. O. Box 62, Oak Ridge. TN 37831: prices available from (615) $576-8401$.

Available to the public from the National Technical Information Service, U. S. Department of Commerce, 5285 Port Royal Rd., Springfield, VA 22161 
BAVANAAH RIVER TBCHYOLOGY CENTER

Applied Technology Bection

8RT-CVA-930039

Applied Physics Group

\section{Reycords}

Criticality

DWPF

Melter

Batch one sludge

NOCLEAR CRITICAIITY BAPBTY EVALUATION

DWRE MELTER - BATCE $1(0)$

December 1, 1993

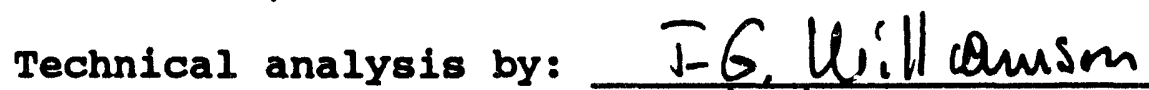

T. G. Wilitamson, Ext. 5-5999

Technical review by: Senior scientigf R. W. Rathbun, Ext. 5-8232

APPROVALS

Task Leader, APG Criticality Methods and Analysis

Manager, Applied Physics Group (APG)

Authorized Derivative Classifier Review

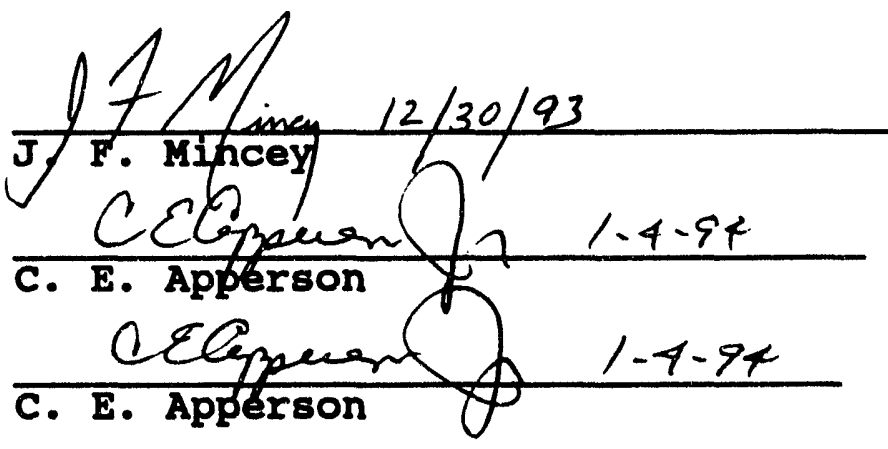

Distribution:

I.M. Papouchado, 773-A

J.F. Ortaldo, 704-S

L.F. Landon, 704-T

J.A. Gentilucci, 704-S

R.E. Eibling, 704-T

H.H. Elder,

704-S

J.H. Gray,

A.G. Sarrack,

N.H. Kuehn,

773-A

992-1ผ

W.T. Goldston,

704-1T

704-S

M.J. Plodinec,

773-A,

J.W. Ray,

$704-35 s$

B. Mangiante,

992-1W

M.R. Buckner,

$773-42 A$

J.F. Mincey,

$773-22 A$

Tech. Info. Man., 703-42A

E.W. Holtzscheiter, 773-A

C.T. Randall, 704-T

J.T. Carter,

704-1T

w.s. Durant,

A.P. Gouge,

J.R. Fowler,

R.A. Jacobs,

N.E. Bibler,

D.A. Sharp,

B.C. Ha,

992W-1

221-F

704-Z

704-T

773-A

992W-1

773-A

703-H,

M.C. Chandler,

W.A. Wagner,

704-27s

T.G. Williamson,

$773-42 A$

C.E. Apperson,

APG Files, 


\subsection{INYRODUCYION}

The Savannah River Site (SRS) High Level Nuclear Waste will be vitrified in the Defense Waste Processing Facility (DWPF) for long term storage and disposal. This is a preliminary safety evaluation for the Melt Cell of the DWPF vitrification process for Batch 1 waste.

This evaluation demonstrates that the material in the Melt Cell remains subcritical for the contents of Batch 1 which contains uranium with less than 1 by weight U-235 (1).

\subsection{DEBCRIPTION}

Waste salt solution is processed in the Tank Farm In-Tank Precipitation process to remove cesium-137 and to adsorb strontium on monosodium titanate (MST). The filtered tetraphenylborate slurxy is then washed in the DWPF Late Wash Facility (LWF) before it is fed to the DWPF salt Processing Cell (SPC). In the salt processing Cell the precipitate slurry is processed in the Precipitate Reactor (PR). The Precipitate Hydrolysis Aqueous (PHA) product from the PR is then combined with the sludge feed and the frit in the DWPF Chemical process Cell (CPC) to produce a melter feed. In the Melt Cell the waste is immobilized in a glass matrix and transferred to sealed canisters.

\subsection{REQUIREUEMYS DOCUUEMATIOA}

There are no specific documents which apply uniquely to this evaluation.

\subsection{MEYHODOLOCY}

The JOSHUA (J70) Nuclear Criticality Safety Module (2) HRXN was used for this analysis. HRXN computes the atom densities for mixtures and combines them with the Hansen-Roach 16group nuclear cross sections to calculate infinite system multiplication factors and to prepare cross sections for transport codes. ANISN solves the one-dimensional radiation transport equation in the discrete ordinates approximation.

Calculation biases for these modules have been established by clark for uranium and plutonium $(3,4)$. The DWPF waste contains uranium, plutonium and traces of other actinides, however, the primary fissile material is uranium. For uranium systems with a hydrogen-to-fissile (H/F) of 100, HRXN-ANISN calculates a $K_{e f f}$ of 0.97 for a critical system. At this point on the bias curve, $H / F=100$, the calculated multiplication factor of 0.97 is at a minimum so its use for other H/F ratios is conservative. With a safety factor of 0.05 a Keff of 0.92 would be safe. For plutonium systems at the same $\mathrm{H} / \mathrm{F}$ ratio, HRXN-ANISN calculates a $K_{\text {eff }}$ of 1.00 
for a critical system so a calculated multiplication factor of 0.92 would be safe for plutonium. Because of the lack of experimental data, there are no bias corrections for other materials, such as iron, manganese, aluminum and sodium. The safety margin of 0.05 is sufficient to cover the bias for these materials.

\subsection{DI8C08sION OF CONMINGENCIEB}

This evaluation is for feed to the melter in which the only fissile materials are in Batch 1 sludge. Batch 1 sludge contains uranium enriched to less than $18 \mathrm{U}-235$ (1). The evaluation demonstrates that the melter is safe from a criticality standpoint as long as the U-235 enrichment remains below 408 and there are no mechanisms to separate the fissile material from other metal oxides. This calculation assumes that the melt mixture is near the optimum hydrogen-to-fissile ratio and that the neutron poisons, boron and lithium, are not present. Because of the conservatism of assuming optimum $\mathrm{H} / \mathrm{F}$ ratios and the assumption that all of the boron and lithium poisons are removed, and, because of the large margin between $U-235$ enrichments of $40 \%$ and less than it, a double contingency analysis was not performed. Assurance must be given that the sludge feed is properly represented by reference 6 and that there is no credible mechanism for isolating the fissile materials.

This analysis is for Batch 1 feed in a melter which contains no fissile materials from previous runs. For different feed material compositions and for multiple batches, additional evaluations must be performed.

\subsection{EVILUATIOA AMD RBBULTS}

Clark (5) has analyzed the melter for the case in which the appropriat! amount of frit has not been added and the melter inventory becomes saturated with waste oxides. He analyzed for uranium enriched to $2.66 \% \mathrm{U}-235$ and plutonium with $60.83 \% \mathrm{Pu}-239$. For this case HRXN calculates a safe infinite multiplication factor, $K_{\text {inf, }}$ of 0.075 . Clark also has shown that the system remains safe if the fissile isotope content is doubled.

Feed material for the melter comes from the slurry Mix Evaporator (SME) as an aqueous slurry containing 58 weight percent water, This water is driven off in the melter. Contents of the feed and the glass are listed in Table 1 (6). For this analysis the manganese, magnesium and sodium formates have been converted to an equivalent quantity of metal oxides. 
Table 1

Melter Composition

\begin{tabular}{|c|c|c|c|c|}
\hline Vater & $\begin{array}{r}\mathrm{Lb} / \mathrm{hr} \\
340.03\end{array}$ & $\begin{array}{l}\text { Wt Erac. } \\
5.79 \mathrm{z}-01\end{array}$ & $\mathrm{Lb} / \mathrm{hr}$ & Wt Erac. \\
\hline $\mathrm{Al}_{2} \mathrm{O}_{3}$ & 10.28 & $1.75 \mathrm{E}-02$ & 10.17 & $4.56 \mathrm{~B}-02$ \\
\hline $\begin{array}{l}\mathrm{B}_{2} \overline{\mathrm{O}}_{3} \cdot \\
\mathrm{Ca}\left(\mathrm{NO}_{2}\right)_{2}\end{array}$ & $\begin{array}{r}12.96 \\
2.61\end{array}$ & $\begin{array}{l}2.21 \mathrm{~B}-02 \\
4.44 \mathrm{~B}-03\end{array}$ & 17.25 & $7.74 \mathrm{~B}-02$ \\
\hline $\mathrm{Cu}(\mathrm{COOH})_{2}$. & 1.55 & $2.64 B-03$ & & \\
\hline $\begin{array}{l}\mathrm{Fe}_{2} \mathrm{O}_{3} \\
\mathrm{FeO}\end{array}$ & 23.73 & $4.04 \mathrm{E}-02$ & $\begin{array}{r}21.14 \\
2.11\end{array}$ & $\begin{array}{l}9.49 \mathrm{~B}-02 \\
9.49 \mathrm{~B}-03\end{array}$ \\
\hline $\begin{array}{l}\mathrm{H}_{3} \mathrm{BO}_{3} \\
\mathrm{KCOOH}\end{array}$ & $\begin{array}{l}8.08 \\
9.48\end{array}$ & $\begin{array}{l}1.38 \mathrm{~B}-02 \\
1.61 \mathrm{E}-02\end{array}$ & & \\
\hline $\mathrm{K}_{2} \mathrm{O}$ & 0.11 & $1.92 \mathrm{~B}-04$ & 5.38 & $2.41 . \mathrm{B}-02$ \\
\hline $\mathrm{II}_{2} \mathrm{O}$ & 11.34 & $1.93 \mathrm{~B}-02$ & 11.23 & $5.04 E-02$ \\
\hline$(\operatorname{Li6})_{2} \mathrm{O}$ & 0.85 & $1.45 \mathrm{E}-03$ & 0.84 & $3.78 \mathrm{E}-03$ \\
\hline$(\mathrm{L} 17)_{2} \mathrm{O}$ & 10.49 & $1.79 \mathrm{I}-02$ & 10.39 & $4.66 \mathrm{E}-02$ \\
\hline MgO & 4.67 & $7.96 \mathrm{E}-03$ & 4.63 & $2.08 \mathrm{~B}-02$ \\
\hline $\mathrm{MnO}_{2}$ & 3.18 & $5 \cdot 41 E-03$ & & \\
\hline Mno & & & 2.77 & $1.24 B-02$ \\
\hline $\mathrm{Na}_{2} \mathrm{O}$ & 14.01 & $2.39 \mathrm{~B}-02$ & 19.57 & $8.78 \mathrm{E}-02$ \\
\hline $\mathrm{NaNO}_{3}$ & 15.84 & $2.70 \mathrm{~B}-02$ & & \\
\hline $\mathrm{SLO}_{2}$ & 126.00 & $2.15 \mathrm{~B}-01$ & 124.70 & $5.60 \mathrm{E}-01$ \\
\hline $\mathrm{U}_{3} \mathrm{O}_{8}$ & 2.33 & $3.97 \mathrm{E}-03$ & 2.31 & $1.03 z-02$ \\
\hline $\mathrm{PuO}_{2}$ & 0.01 & $1.47 \mathrm{E}-05$ & 0.01 & $3.848-05$ \\
\hline Sum & 586.98 & 1.00 & 222.84 & 1.00 \\
\hline $\begin{array}{l}\text { Plow } \\
\text { Density }\end{array}$ & \multirow{3}{*}{\multicolumn{2}{|c|}{$\begin{array}{l}599.1 \mathrm{Lb} / \mathrm{hr} \\
82.65 \mathrm{Lb} / \mathrm{ft}^{3} \\
1.306 \mathrm{~g} / \mathrm{cc} \\
98.08\end{array}$}} & \multirow{3}{*}{\multicolumn{2}{|c|}{$\begin{array}{l}228.0 \mathrm{Lb} / \mathrm{hr} \\
156.6 \mathrm{Lb} / \mathrm{ft}^{3} \\
2.475 \mathrm{~g} / \mathrm{cc} \\
97.78\end{array}$}} \\
\hline & & & & \\
\hline Flow & & & & \\
\hline
\end{tabular}

The materials listed in Table 1, which constitute $98.0 \%$ and $97.7 \%$ of the mass of the feed and the glass respectively, were analyzed with the results shown in Table 2. For these cases the uranium was treated as $\mathrm{U}_{3} \mathrm{O}_{8}$ at $100 \% \mathrm{U}-235$ and plutonium as $\mathrm{PuO}_{2}$ at $1008 \mathrm{Pu}-239$.

Table 2

HRXN Analysis

Materials from Table 1 (JOB 1321)

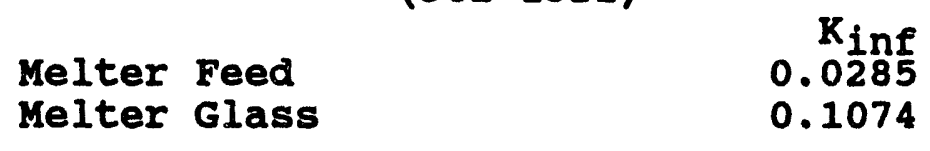

(The notation JOB 1321 indicates that the values in the table are on microfiche DWPF6508 Job 1321) 
These materials contain boron with 19.98 boron-10 and lithium with $7.5 \%$ Lithium-6, both of which are good neutron poisons. An analysis was done for the extreme cases in which all of the boron and lithium were removed and for different water contents in the feed material. These results are in Table 3 .

Table 3

HRXN Analysis

Reduced Boron and Water

(JOB 1321)

Melter Feed

$1 / 10$ water, All B \& Li, $100 \& \mathrm{U}-2350.0429$

$1 / 100$ water, All B \& Li, 100 \& U-235 0.0721

All water, No B Li, 100 \&-235 0.571 .

$1 / 100$ water, No B Li, 100 U-235 1.298

$1 / 100$ water, No $B \& \mathrm{Li}, 408 \mathrm{U}-235$

$1 / 100$ water, $28 \mathrm{~B}$, No Li, $1008 \mathrm{U}-2350.711$

$1 / 100$ water, $18 \mathrm{~B}$, No Li, $1008 \mathrm{U}-2350.992$

Glass

No $\mathrm{B} \& \mathrm{Li}, 100$ \& U-235 1.329

No $B \& L i, 50 \& U-235 \quad 0.956$

No $B \& L i, 40$ \& U-235 0.854

$28 \mathrm{~B}$, No $\mathrm{Li}, 100$ \& U-235 0.848

$18 \mathrm{~B}$, No $\mathrm{Li}, 100$ U-235 1.01

The notation $1 / 10$ water means that the water content was reduced to $1 / 10$ of the value in Table 1 and the mixture density adjusted on the basis that all materials are in solution. The material contents for these cases are listed in Appendix 1. The notation no B L $L, 1 \%$ B or 28 B means that the $\mathrm{B}_{2} \mathrm{O}_{3}, \mathrm{H}_{3} \mathrm{BO}_{3}$ and the $\mathrm{Li}_{2} \mathrm{O}$ contents were reduced and the solution density adjusted accordingly. For the case of $1 / 100$ water the hydrogen-to-fissile ratio, $H / F$, is 151 , which is near the most reactive H/F combination. These data indicate that, even without corrections for finite geometry, and, in the extreme case for which no boron or lithium is included, the melter will always remain subcritical as long as the uranium enrichment remains below $408 \mathrm{U}-235$ and the metal oxides remain with the fissile oxides. If the boron content of the glass is greater than $2 \%$ of the value in Table 1, the melter remains safe even for 100 U-235.

The active volume of the melter is cylindrical, 6 feet $(1.83$ $\mathrm{m})$ in diameter with a nominal height 34 inches $(0.86 \mathrm{~m})$ (7). The melter nominally contains $5.61 \times 10^{3} \mathrm{~kg}$ glass. For the weight fractions listed in Table 1, the glass contains 57.8 $\mathrm{kg} \mathrm{U} \mathrm{U}_{8}$ and $216 \mathrm{~g} \mathrm{PuO}_{2}$. At $40 \mathrm{q}$ uranium enrichment and 1008 Pu-239 this mass corresponds to $19.6 \mathrm{~kg} \mathrm{U}-235$ and $190 \mathrm{~g} \mathrm{Pu}-$ 239. A cylinder with radius $0.91 \mathrm{~m}$ and thickness $0.86 \mathrm{~m}$ is a 
flat, "high leakage" geometry. An ANISN calculation with the glass material and no boron or lithium $\left(K_{i n f}=1.329\right)$ in an infinite planar geometry $0.86 \mathrm{~m}$ thick with $30-\mathrm{cm}$ water reflection on both sides has $K_{\text {eff }}=0.85$ (JOB 867). A correction for radial leakage in this planar geometry reduces $R_{e f f}$ to 0.50 . Thus, if all of the boron and lithium were lost and if $100 \%$ enriched uranium were in the melter and if the material in the melter were constrained to a thickness no greater than $0.86 \mathrm{~m}$, the system would remain safe.

\section{CONCLUSION}

Compositions of the feed material and of the glass from reference 6 have been used to determine the criticality safety of the Melter under normal conditions. These materials remain safe from a criticality standpoint. For a case in which of all of the boron and lithium is lost, the melter remains safe for feed material described in Table 1 with the uranium enriched to no more than $408 \mathrm{U}-235$. For the composition listed in Table 1 this value corresponds to 19.6 $\mathrm{kg} \mathrm{U}-235$ and $190 \mathrm{~g} \mathrm{Pu-239}$. If the boron (19.9\% B-10) content of the glass is greater than $2 \%$ of the value in Table 1 , the melter remains safe even for $1008 \mathrm{U}-235$. The material in the DWPF sludge feed Batch 1 can be processed in the melter cell safely since it contains uranium with less than 1 if by weight U-235 (1).

\section{REFERENCES}

1. J. S. Clemmons, "Nuclear Safety of Extended sludge Processing on Tank 42 and 51 sludge (DWPF sludge Feed Batch One) . (U) ", WSRC-TR-93-115, (1993)

2. H.K. Clark, "JOSHUA Nuclear Criticality Safety Modules", DPSTM-86-700-3, NRTSC, (1987).

3. H. K. Clark, "Subcritical Limits for Uranium-235 Systems" Nucl, Sci. Eng. 81, 351-378, (1982).

4. H. K. Clark, "Subcritical Limits for Plutonium systems" Nucl, Sci. Eng. 79, 65-84, (1981).

5. H. K. Clark, "Nuclear Criticality Safety Assessment of Defense Waste Processing Facility", DPST-82-965, (1982).

6. A. S. Choi, "Material Balance Tables for the DWPF Coupled Feed Flow Sheet with Batch 1 sludge (U)", WSRC-TR-93-203, Rev. 0, (1993).

7. Drawing $W$ 736916, Rev 0 "DWPF Melter Refractory, Dim. Doc." , (1984). 


\section{APPENDIX A}

\section{COMPOSITIONS OF MATERIALS IN MELTER}

The following tables were generated on a spread sheet with the assumption that the materials are in solution and the solution density is determined from

$$
\frac{1}{\rho_{s}}=\sum_{i} \frac{\left(w t . \text { frac. }_{i}\right.}{\rho_{i}}
$$

where the subscript $s$ refers to the solution and 1 to the individual components. Compound densities were taken from the Handbook of Physics and Chemistry, 34th edition.

\begin{tabular}{|c|c|c|c|c|}
\hline \multicolumn{5}{|l|}{ Nelter Feed } \\
\hline to DWPF & $\begin{array}{r}\mathrm{Lb} / \mathrm{hr} \\
340.03\end{array}$ & $\begin{array}{l}\text { Wt. Frac. } \\
5.80 \mathrm{~s}-01\end{array}$ & $\begin{array}{r}\text { Density } \\
1.00\end{array}$ & $\begin{array}{r}\text { Wt. Frac/ } \\
\text { Density } \\
0.5802\end{array}$ \\
\hline $\begin{array}{l}\text { Water } \\
\mathrm{Al}_{2} \mathrm{O}_{3}\end{array}$ & 10.28 & $1.75 \mathrm{z}-02$ & 3.50 & 0.0050 \\
\hline $\begin{array}{l}\mathrm{B}_{2} \mathrm{O}_{3} \cdot \\
\mathrm{Ca}\left(\mathrm{NO}_{3}\right)_{2}\end{array}$ & $\begin{array}{r}12.96 \\
2.61\end{array}$ & $\begin{array}{l}2.21 E-02 \\
4.45 E-03\end{array}$ & $\begin{array}{l}1.84 \\
2.36\end{array}$ & $\begin{array}{l}0.0120 \\
0.0019\end{array}$ \\
\hline $\mathrm{Cu}(\mathrm{COOH})_{2}$. & 1.55 & $2.648-03$ & 1.83 & 0.0014 \\
\hline $\mathrm{Fe}_{2} \mathrm{O}_{3}$ & 23.73 & $4.05 \mathrm{E}-02$ & 5.24 & 0.0077 \\
\hline $\begin{array}{l}\mathrm{H}_{3} \mathrm{BO}_{3} \\
\mathrm{RCOOH}\end{array}$ & $\begin{array}{l}8.08 \\
9.48\end{array}$ & $\begin{array}{l}1.38 \mathrm{~B}-02 \\
1.62 \mathrm{E}-02\end{array}$ & $\begin{array}{l}1.44 \\
1.91\end{array}$ & $\begin{array}{l}0.0096 \\
0.0085\end{array}$ \\
\hline $\mathrm{Ii}_{2} \mathrm{O}$ & 11.34 & $1.93 \mathrm{~B}-02$ & 2.01 & 0.0096 \\
\hline$(I 16)_{2} \mathrm{O}$ & 0.85 & $1.45 z-03$ & & \\
\hline$(\operatorname{Li7})_{2} \mathrm{O}$ & 10.49 & $1.798-02$ & & \\
\hline MgO & 4.67 & $7.97 \mathrm{~B}-03$ & 3.58 & 0.0022 \\
\hline $\mathrm{KnO}_{2}$ & 3.18 & $5.42 \mathrm{E}-03$ & 5.03 & 0.0011 \\
\hline $\mathrm{Na}_{2} \mathrm{O}$ & 14.01 & $2.39 \mathrm{z}-02$ & 2.27 & 0.0105 \\
\hline $\mathrm{NaNO}_{3}$ & 15.84 & $2.70 \mathrm{~B}-02$ & 2.26 & 0.0120 \\
\hline $\mathrm{SiO}_{2}$ & 126.00 & $2.15 \mathrm{~B}-01$ & 2.32 & 0.0927 \\
\hline $\mathrm{U}_{3} \mathrm{O}_{8}$ & 2.33 & $3.97 \mathrm{E}-03$ & 8.39 & 0.0005 \\
\hline $\mathrm{PuO}_{2}$ & 0.01 & $1.47 \mathrm{E}-05$ & 11.46 & $1.287 \mathrm{E}-06$ \\
\hline \multirow[t]{2}{*}{ sum } & \multirow{2}{*}{586.08} & \multirow{2}{*}{\multicolumn{2}{|c|}{$g / c c$}} & 0.75 \\
\hline & & & & 1.325 \\
\hline
\end{tabular}


Melter Feed

1/10 Water

Water
$\mathrm{Al}_{2} \mathrm{O}_{3}$
$\mathrm{~B}_{2} \mathrm{O}_{3} \cdot$
$\mathrm{Ca}\left(\mathrm{NO}_{3}\right)_{2}$
$\mathrm{Cu}(\mathrm{COOH})_{2}$
$\mathrm{Fe}_{2} \mathrm{O}_{3}$
$\mathrm{H}_{3} \mathrm{BO}_{3}$
$\mathrm{KCOOH}$
$\mathrm{LI}_{2} \mathrm{O}$
$(\mathrm{L} 16)_{2} \mathrm{O}$
$(\mathrm{LI})_{2} \mathrm{O}$
$\mathrm{MgO}_{2} \mathrm{O}$
$\mathrm{MnO}_{2}$
$\mathrm{Na}_{2} \mathrm{O}$
$\mathrm{NaNO}_{3}$
$\mathrm{SiO}_{2}$
$\mathrm{O}_{3} \mathrm{O}_{8}$
$\mathrm{PuO}_{2}$

sum

Melter Feed

1/100 Water

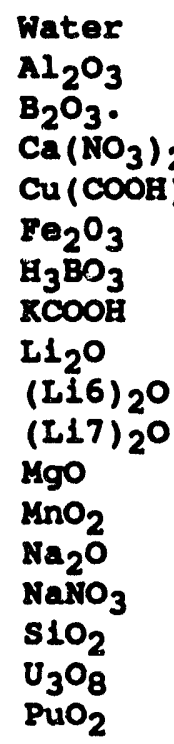

sum
Lb/hr Wt. Frac.

34.03

10.28

12.96

2.61

1.55

23.73

8.08

9.48

11.34

0.85

10.49

4.67

3.18

14.01

15.84

126.00

2.33

0.01

280.08

$1.22 \mathrm{E}-01$
$3.67 \mathrm{E}-02$

4. 63E-02

9. 31E-03

$5.53 \mathrm{E}-03$

8. 47 E-02

2. 88E-02

3. 38E-02

4. 05E-02

3. 04E-03

3. 75E-02

$1.67 \mathrm{~B}-02$

1. 13B-02

5. 008-02

5. 66 $\mathrm{E}-02$

4. 501-01

8. 31z-03

3. 09B-05

Density

1.00

3.50

1.84

2.36

1.83

5.24

1.44

1.91

2.01

3.58

5.03

2.27

2.26

2.32

8.39

11.46

Density g/cc

Wt. Frac/

Density

0.1215

0.0105

0.0251

0.0039

0.0030

0.0162

0.0200

0.0177

0.0201

0.0047

0.0023

0.0220

0.0250

0.1939

0.0010

2. 692E-06

2.054

Wt. Prac/

Density

wb/hr Wt. Frac.

3.40

1. 36E-02

4. 12E-02

10.28

5. 20z-02

1. 05E-02

2.61

$6.21 \mathrm{~s}-03$

9. 51E-02

23.73

$9.51 \mathrm{~B}-02$
$3.24 \mathrm{E}-02$

8.08

9.48

11.34

3. 80B-02

$4.55 \mathrm{E}-02$

0.85

10.49

4.67

3. 41E-03

4. 21E-02

3.18

14.01

$1.87 \mathrm{E}-02$

1. 27 $\mathrm{E}-02$

5. 62B-02

$6.35 \mathrm{~B}-02$

$126.00 \quad 5.05 \mathrm{E}-01$

2.33

$9.33 \mathrm{E}-03$

3. $46 E-05$

Density

1.00

3.50

1.84

2.36

1.83

5.24

1.44

1.91

2.01

0.0136

0.0118

0.0282

0.0044

0.0034

0.0182

0.0225

0.0199

0.0226

3.58

5.03

2.27

2.26

2.32

8.39

11.46

0.0052

0.0025

0.0247

0.0281

0.2177

0.0011

0.01

1.00

249.45

Density $g / c c$ 


\begin{tabular}{|c|c|c|c|c|}
\hline \multicolumn{5}{|l|}{ Melter Feed } \\
\hline No Boron or & ithium & & & Wt. Frac/ \\
\hline Water & $\begin{array}{r}\mathrm{Ib} / \mathrm{hr} \\
340.03\end{array}$ & $\begin{array}{r}\text { Wt. Frac. } \\
6.14 \mathrm{~B}-01\end{array}$ & $\begin{array}{r}\text { Density } \\
1.00\end{array}$ & $\begin{array}{r}\text { Density } \\
0.6141\end{array}$ \\
\hline $\mathrm{Al}_{2} \mathrm{O}_{3}$ & 10.28 & $1.86 \mathrm{~B}-02$ & 3.50 & 0.0053 \\
\hline $\mathrm{B}_{2} \mathrm{O}_{3}$. & 0.00 & $0.00 \mathrm{~s}+00$ & 1.84 & 0.0000 \\
\hline $\mathrm{Ca}\left(\mathrm{NO}_{3}\right)_{2}$ & 2.61 & $4.718-03$ & 2.36 & 0.0020 \\
\hline $\mathrm{Cu}(\mathrm{COOH})_{2}$. & 1.55 & $2.80 \mathrm{~s}-03$ & 1.83 & 0.0015 \\
\hline $\mathrm{Fe}_{2} \mathrm{O}_{3}$ & 23.73 & $4.29 \mathrm{~B}-02$ & 5.24 & 0.0082 \\
\hline $\mathrm{H}_{3} \mathrm{BO}_{3}$ & 0.00 & $0.008+00$ & 1.44 & 0.0000 \\
\hline RCOOH & 9.48 & $1.71 \mathrm{~B}-02$ & 1.91 & 0.0090 \\
\hline $\mathrm{LI}_{2} \mathrm{O}$ & 0.00 & $0.008+00$ & 2.01 & 0.0000 \\
\hline$(I \mathrm{I} 6)_{2} \mathrm{O}$ & 0.00 & $0.00 \mathrm{~s}+00$ & & \\
\hline$(217)_{2} 0$ & 0.00 & $0.008+00$ & & \\
\hline Mgo & 4.67 & $8.448-03$ & 3.58 & 0.0024 \\
\hline $\mathrm{MnO}_{2}$ & 3.18 & $5.738-03$ & 5.03 & 0.0011 \\
\hline $\mathrm{Na}_{2} \mathrm{O}$ & 14.01 & $2.53 \mathrm{E}-02$ & 2.27 & 0.0111 \\
\hline $\mathrm{NaNO}_{3}$ & 15.84 & $2.86 z-02$ & 2.26 & 0.0127 \\
\hline $\mathrm{SiO}_{2}$ & 126.00 & $2.288-01$ & 2.32 & 0.0981 \\
\hline $\mathrm{O}_{3} \mathrm{O}_{8}$ & 2.33 & $4.208-03$ & 8.39 & 0.0005 \\
\hline $\mathrm{PuO}_{2}$ & 0.01 & $1.56 \mathrm{~s}-05$ & 11.46 & $1.362 \mathrm{E}-06$ \\
\hline Sum & 553.70 & 1.00 & & 0.77 \\
\hline & & nsity & cc & 1.306 \\
\hline Melter & & & & \\
\hline No $B$ & 100 wate & & & Wt. Frac/ \\
\hline & $\mathrm{Lb} / \mathrm{hr}$ & Wt. Frac. & Density & Density \\
\hline Water & 3.40 & $1.578-02$ & 1.00 & 0.0157 \\
\hline $\mathrm{Al}_{2} \mathrm{O}_{3}$ & 10.28 & $4.74 z-02$ & 3.50 & 0.0135 \\
\hline $\mathrm{B}_{2} \overline{\mathrm{O}}_{3}$. & 0.00 & $0.00 \mathrm{~s}+00$ & 1.84 & 0.0000 \\
\hline $\mathrm{Ca}\left(\mathrm{NO}_{3}\right)_{2}$ & 2.61 & $1.20 \mathrm{~s}-02$ & 2.36 & 0.0051 \\
\hline $\mathrm{Cu}(\mathrm{COOH})_{2}$ & 1.55 & $7.138-03$ & 1.83 & 0.0039 \\
\hline $\mathrm{Fe}_{2} \mathrm{O}_{3}$ & 23.73 & $1.09 \mathrm{~B}-01$ & 5.24 & 0.0209 \\
\hline $\mathrm{H}_{3} \mathrm{BO}_{3}$ & 0.00 & $0.00 z+00$ & 1.44 & 0.0000 \\
\hline RCOOH & 9.48 & $4.37 \mathrm{E}-02$ & 1.91 & 0.0229 \\
\hline $\mathrm{LI}_{2} \mathrm{O}$ & 0.00 & $0.00 \mathrm{~s}+00$ & 2.01 & 0.0000 \\
\hline$(I 16)_{2} 0$ & 0.00 & $0.00 \mathrm{E}+00$ & & \\
\hline$(\mathrm{LIT})_{2} \mathrm{O}$ & 0.00 & $0.00 \mathrm{z}+00$ & & \\
\hline MgO & 4.67 & $2.15 \mathrm{~B}-02$ & 3.58 & 0.0060 \\
\hline $\mathrm{MnO}_{2}$ & 3.18 & $1.46 \mathrm{~B}-02$ & 5.03 & 0.0029 \\
\hline $\mathrm{Na}_{2} \mathrm{O}$ & 14.01 & $6.45 \mathrm{E}-02$ & 2.27 & 0.0284 \\
\hline $\mathrm{NaNO}_{3}$ & 15.84 & $7.30 \mathrm{~s}-02$ & 2.26 & 0.0323 \\
\hline $\mathrm{SiO}_{2}$ & 126.00 & $5.80 \mathrm{z}-01$ & 2.32 & 0.2502 \\
\hline $\mathrm{U}_{3} \mathrm{O}_{8}$ & 2.33 & $1.07 \mathrm{~B}-02$ & 8.39 & 0.0013 \\
\hline $\mathrm{PuO}_{2}$ & 0.01 & $3.98 \mathrm{z}-05$ & 11.46 & $3.474 z-06$ \\
\hline Sum & 217.08 & 1.00 & & 0.40 \\
\hline & & ty & & 2.481 \\
\hline
\end{tabular}


Glaes

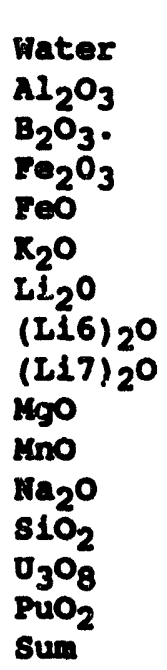

Lb/hr Wt. Prac.

0.00

10.17

17.25

21.14

2.11

5.38

11.23

0.84

10.39

4.63

2.77

19.57

124.70

2.31

0.01

221.27

$0.00 \mathrm{z}+00$

4. 601-02

7. 80z-02

$9.55 \mathrm{E}-02$

9. 55E-03

2. 43E-02

5. $08 z-02$

3. 81R-03

4.695-02

2. 098-02

1. 25B-02

8. 84E-02

5. 64E-01

1.045-02

3. 87 E-05

Denelty 1.00

g/ce

Density
1.00
3.50
1.84
5.24
5.70
2.32
2.01

3.58
5.45
2.27
2.32
8.39
11.46

G1a8:

vater

$\mathrm{Al}_{2} \mathrm{O}_{3}$

$\mathrm{B}_{2} \mathrm{O}_{3}$.

$\mathrm{Pe}_{2} \mathrm{O}_{3}$

IeO

$\mathrm{K}_{2} \mathrm{O}$

$\mathrm{LI}_{2} \mathrm{O}$

(LI6) ${ }_{2} \mathrm{O}$

(L17) $2^{\circ}$

igo

uno

$\mathrm{Na}_{2} \mathrm{O}$

$\mathrm{SLO}_{2}$

$\mathrm{O}_{3} \mathrm{O}_{8}$

$\mathrm{PuO}_{2}$

sum
No $B$ or It

Lb/hr

0.00

10.17

0.00

21.14

2.11

5.38

0.00

0.00

0.00

4.63

2.77

19.57

124.70

2.31

0.01

192.79
Nt. Prac.

$0.00 z+00$

5. 28z-02

$0.00 z+00$

1. 108-01

1.108-02

2. 795-02

$0.00 z+00$

$0.00 z+00$

$0.008+00$

2. 403-02

1. 44E-02

1. 025-01

6. 478-01

1. 208-02

4. 44E-05

1.00

Density
Denelty

1.00

3.50

1.84

5.24

5.70

2.32

2.01

3.58

5.45

2. 27

2.32

8.39

11.46

g/ce
Wt Prac/

Density

0.0000

0.0131

0.0423

0.0182

0.0017

0.0105

0.0252

0.0058

0.0023

0.0390

0.2429

0.0012

$3.3745-06$

0.40

2.486

Wt Erac/

Deneity

0.0000

0.0151

0.0000

0.0209

0.0019

0.0120

0.0000

0.0067

0.0026

0.0447

0.2788

0.0014

$3.873 \mathrm{E}-06$

0.38

2.603 

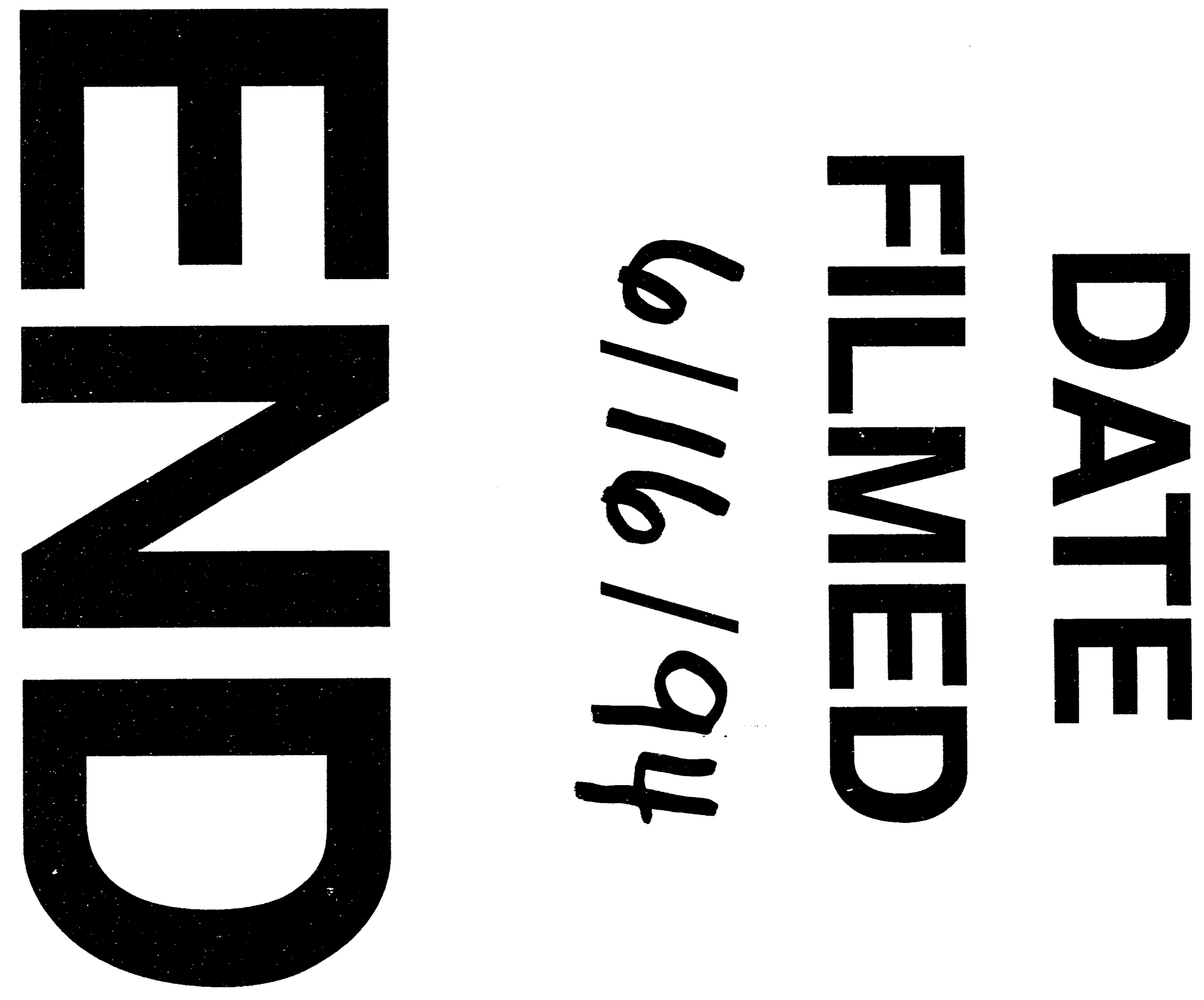
